\title{
O OBSERVADOR NO ESCRITÓRIO, UM TEMPO FILTRADO PELO MODO DE VER
}

Juliana Ribeiro Silva*

RESUMO: Este trabalho tem como objetivo apresentar uma discussão sobre o diário de Drummond, intitulado $O$ observador no escritório, demonstrando como a obra transcende as questões do gênero, já que não se configura como um diário convencional, indo além dos registros mais íntimos e das reflexões do dia a dia. O livro reúne registros de fatos políticos, literários e pessoais datados de 1943 a 1977, publicados no Jornal do Brasil em 1981-1982 e, organizados pelo autor, em 1985. Por ir além dos registros pessoais, recortando da história aquilo que o poeta acreditava ser essencial para traduzir sua época, ao falar de si dos outros, o dí́rio de Drummond, revela-se como uma heterobiografia Sendo assim, essas anotacões que se aproximamo biografia. Sendo assim, essas anotaçoes que se aproximam or da crônica, ora da escrita intima, ora do registro historico e documental fazem deste diario um livro precioso no qual o leitor encontrará "um tempo filtrado pelo modo de ver" do observador.

PALAVRAS-CHAVE: Modernismo; Carlos Drummond de Andrade; Escritas do eu; Diário.
* ju_ribeiroport@hotmail.com

Mestre em Estudos Literários pela Universidade Federal de Uberlândia - UFU.

ABSTRACT: This work aims to present a discussion about Drummond's diary, named as "The observer at the office" "O observador no escritório", demonstrating how the work transcends the gender issues, since it is not configured as a conventional the gender issues, since it is not configured as a conventional
diary, and goes beyond the most intimate records and the day by diary, and goes beyond the most intimate records and the day by literary and personal dated from 1943 to 1977, published at Brazil Journal in 1981-1982 and organized by the author in 1985 . Because of going beyond the personal records, cutting from the story in the moment that the poet believed that it was essential (this Drums is time, when he talks about himself anc Drummond's diary, is revealed as a heterobiography.

KEYWORDS: Modernism; Carlos Drummond de Andrade; Written of me; Dairy. 
"Seu livro é de hoje, de ontem e de amanhã

Mário de Andrade

A epígrafe acima, retirada de uma carta de Mário de Andrade a Carlos Drummond, referia-se ao primeiro livro do poeta mineiro, Alguma poesia, mas poderia também ser usada para descrever $O$ observador no escritório, diário daquele que sempre se mostrou atento aos "homens presentes" e ao "tempo presente". Nesta obra, os registros do cotidiano e da intimidade misturam-se com anotações críticas que hoje se revelam como relatos históricos impregnados pela visão de um observador atento, lúcido e, muitas vezes, encurralado pelos desdobramentos dos fatos. Nesse sentido, o Observador é um livro que perdura, pois não só descreve o período vivido e anotado pelo autor, mas também torna possível que o leitor, mediante esses registros, estabeleça uma relação entre o passado e a atualidade do país.

Essa relação com o tempo, esse desejo de recortar da história aquilo que acreditava ser essencial para traduzir uma época, identificamos também no diário intitulado $O$ observado no escritório. Nele, o autor apresenta registros de fatos políticos, literários e da vida pessoal datados de 1943 a 1977. Parte dessas anotações foi publicada em uma coluna no Caderno B do Jornal do Brasil em 1980-1981. Drummond manteve o diário durante anos, mas só decidiu publicar alguns trechos, no jornal, quando já não se dedicava mais a esses registros. A decisão de reunir suas anotações em livro só aconteceu em 1985 , quando o autor parece ter percebido que, ao oferecer ao leitor "o eco de um tempo abolido", também estaria "resgatando sua nostalgia e fornecendo matéria para conversa de pessoas velhas e novas".

Além dos trechos anteriormente publicados no Jornal do Brasil, há, nessa obra, trechos que até o momento da seleção para o livro eram inéditos. Nos vários cadernos de anotações, ainda existem registros mais íntimos que, por vontade de Drummond, não foram publicados no jornal, nem no livro, preservados apenas para que as novas gerações da família "Andrade" pudessem conhecer parte da própria história contada por alguém que estava integrado a ela.

Em entrevista concedida à filha Maria Julieta em 22 de janeiro de 1984, no jornal O Globo, Drummond declarou que seu diário seria um "desabafo abafado", isso porque, segundo o poeta, aquelas anotações seriam apenas confissões íntimas. Quando perguntado se a escrita do diário seria uma forma de evitar o divã, Carlos Drummond respondeu afirmativamente, porém destacou que os desabafos eram apenas para ele mesmo, não havia intenção de transformá-los em ato público, veiculando-os no jornal ou reunindo-os em um livro, o que ele reiterou no prefácio do diário. Ainda nessa entrevista, o observador, mesmo confirmando para a entrevistadora 
que seu diário era uma forma de terapia, destacou a importância deste como um registro do cotidiano, dos fatos políticos, de situações curiosas, de lembranças sobre os amigos e também como uma maneira de conservar aspectos mais particulares para outras gerações da família.

No decorrer da entrevista, o poeta mineiro confessa à filha que, ao ver os cadernos com as anotações, pensou que não valeria a pena nem mesmo guardá-los, mas depois de folheá-los mais atentamente, acabou percebendo a importância daquelas anotações como registro de si mesmo, de suas reações e de suas impressões sobre os fatos e a sociedade da época. Essa constatação da importância daquelas anotações fez com que ele decidisse organizar e levar os registros na forma de livro/diário ao espaço público.

A primeira edição d'O Observador, publicada pela editora Record em 1985, reúne mais de trezentos trechos e um apêndice com o título "Uma carta de Luís Carlos Prestes". Essas anotações são organizadas por ano, e há trechos que além da data, ganham títulos; há outros, porém, sem nenhuma dessas indicações. A frequência irregular desses registros pode ser notada quando se compara a quantidade de registros entre os anos, pois há períodos, como o ano de 1968 , em que as anotações são escassas, há ano, como em 1949, que não apresenta nenhum registro e outros com número maior de trechos, como em 1945.
Ao lado de pessoas da família como os pais do poeta, a esposa Dolores, a filha Maria Julieta, o tio Elias, a tia Nhanhá, a tia Zizinha ou de convivência mais próxima como a cozinheira Melca, as empregadas, os médicos e os vizinhos, também desfila um número quase incontável de figuras históricas e literárias, entre eles, políticos, jornalistas, intelectuais e artistas de modo geral. Entre os escritores, ganham espaço na narrativa: Mário de Andrade, Manuel Bandeira, Cecília Meireles, Vinicius de Moraes, Paulo Mendes Campos, Murilo Mendes, Álvaro Moreyra, Oswald de Andrade, João Cabral, Fernando Sabino, Pablo Neruda, Clarice Lispector, Abgar Renault, Guimarães Rosa, Ribeiro Couto, Cyro dos Anjos e outros. Do meio artístico, são mencionados também o pintor Portinari, o cantor e compositor Chico Buarque, o escultor Max Grossman, entre outros. Das figuras históricas, destacam-se: os presidentes Getúlio Vargas, João Goulart e Jânio Quadros, além de personalidades que também se envolveram no meio político, como Francisco Campos, Gustavo Capanema e o jornalista Carlos Lacerda.

De 1943 a 1977, Drummond registrou um país sacudido por mudanças significativas, passando, durante essa época, pelo final do Estado Novo, pelo fim da Segunda Guerra Mundial, pela democratização do Brasil, pela modernização e industrialização brasileira implantadas nos governos Vargas e JK, pelo período político Populista e pela Ditadura 
2. ANDRADE. O observador no escritório, p. 7. militar. Como testemunha atenta e crítica desse tempo, o narrador conta com propriedade aquilo que via acontecer em seu país e acaba apresentando, a partir de seu ponto de vista, um quadro daquele contexto histórico.

E é desta forma que Drummond anota os "fatos" e desnuda as transformações vivenciadas naquele período. De sua mesinha de escritório, o observador enxerga o seu tempo e, seja como poeta, como observador cronista ou como observador de si, não consegue escapar do "impulso de escrever"2 que o move. Em "CIAO", crônica de despedida, publicada no Jorna do Brasil em 29 de setembro 1984, Drummond descreve o que foi seu trabalho como cronista e o que afirma a respeito de como viu e anotou sua época com riso e zanga serve também como uma excelente descrição para seu diário:

Assistiu, sentado e escrevendo, ao desfile de 11 presidentes da República, mais ou menos eleitos (sendo um bisado), sem contar as altas patentes militares que se atribuíram esse título. Viu de longe, mas de coração arfante, a Segunda Guerra Mundial, acompanhou a industrialização do Brasil, os movimentos populares frustrados, mas renascidos, os ismos de vanguarda que ambicionavam reformular para sempre o conceito universa de poesia; anotou as catástrofes, a Lua visitada, as mulheres lutando a braço para serem entendidas pelos homens; as pequenas alegrias do cotidiano, abertas a qualquer um, que são certamente as melhores. Viu tudo isso, ora sorrindo ora zangado, pois a zanga tem seu lugar mesmo nos temperamentos mais aguados. Procurou extrair de cada coisa não uma lição, mas um traço que comovesse ou distraísse o leitor, fazendo-o sorrir, se não do acontecimento, pelo menos do próprio cronista, que às vezes se torna cronista do seu umbigo, ironizando-se a si mesmo antes que outros o façam. ${ }^{3}$

Ao contrário do que possa parecer inicialmente, o Drummond presente no diário não é um mero observador como sugere o título, trata-se, na verdade de uma testemunha, que está inserida no processo ao mesmo tempo em que o narra. Mesmo sentindo-se impotente diante dos acontecimentos, assistindo "sentado e escrevendo", o autor mostra-se participante de outra maneira, por meio da observação e da escrita, o que ele confessa no trecho de transcrição do documentário “No caminho de Drummond”, dirigido por Wagner Morales:

Para ver os acontecimentos do mundo não é preciso participar deles. Eu participo vendo, espiando, olhando, da janela do meu escritório, porque não sou um ser muito gregário, um ser que se mete em grandes atividades para reformar o mundo. Não, não tenho essa pretensão.

Apesar de classificar-se no título e em um dos prefácios como um "observador", essa atitude passiva de quem apenas
3. ANDRADE. CIAO, $s / p$
4. Transcrição do documentário No caminho de Drummond. Disponivel em: <http://www. pactoaudiovisual.com.br/mestres final/drummond/transcricao.htm Acessado em: 05/06/2015. 
5. ANDRADE. O observador no escritório, p. 8.

6. BLANCHOT. O livro por vir, p. 270

7. Apesar de o dicionário não prever "diarista" como aquele que escreve um diário e por não haver nenhuma outra palavra na língua portuguesa para designálo, o termo será adotado neste trabalho quando nos referirmos ao narrador de $O$ observador. $O$ mesmo termo também é utilizado por Lejeune. enxerga os fatos sem influir neles não é o que fica evidente no diário. A dúvida apontada pelo "talvez" usado na apresentação do livro em "Fui, talvez, observador no escritório" ${ }^{\text {faz pen- }}$ sar que, na verdade, não se trata de alguém que está de fora, distante do fato que narra, mas sim de um sujeito que não restringe seu trabalho à mera observação e simples registro.

Com ou sem pretensão, é na escrita que o autor revela que fez muito mais que espiar da janela do escritório. Seu diário tornou-se um espaço de refúgio, onde podia dizer o que queria, fazer desabafos pessoais ou ainda expor sua visão crítica do país, tarefa difícil em tempos de censura. Mesmo afirmando que não era um ser que se "metia em grandes atividades para reformar o mundo", Drummond, à maneira dele, não só participou, mas sofreu e vibrou com os acontecimentos de seu tempo.

Em OObservador no escritório, o leitor encontrará dois prefácios escritos pelo próprio autor. No primeiro, Drummond conta que manteve o diário por muito tempo, destacando que não escrevia com a regularidade característica dos textos de escrita íntima. Suas anotações não estavam submetidas “à cláusula aparentemente leve"6, apontada por Blanchot: o respeito ao calendário. Dessa forma, podemos dizer que o que temos neste diário é um conjunto de fragmentos selecionados pelo próprio diarista ${ }^{7}$, sendo que alguns desses registros foram salvos de um incêndio provocado por ele mesmo e, só depois, reunidos e organizados pelo poeta. Trata-se de um diário que foi se constituindo por meio desse agrupamento de anotações pessoais, dos registros de fatos políticos e literários que interessavam ao observador no calor da escrita e que, segundo as escolhas feitas por ele, após o "capricho da destruição", também interessariam ao leitor.

Essa seleção dos trechos que seriam publicados e a destruição de outros levam a crer que ao privilegiar determinadas anotações, o autor elaborava um relato de sua trajetória feito de maneira racional e até mesmo com preocupações estéticas. As escolhas sinalizam que Drummond não pretendia fazer de seu diário uma apresentação de si, revelando intimidades e confidências, mas havia ali uma atenção voltada para a importância documental e também para a literariedade do livro que "produzia".

No segundo prefácio, denominado "poema-prefácio" por Rodrigo Jorge em seu artigo "Retratos, espelhos e outras faces no diário de Drummond”, Drummond tenta explicar o que o motivou a escrever essas anotações. Vejamos o texto na íntegra:

Por que se escrevem diários? Por que notadamente os escritores gostam de escrevê-los, dissipando o tempo que deveria ser consagrado a viver ou a produzir escritos públicos? Admite-se que o político e, de modo geral, o homem de ação se empenhem em manter registro continuado de 
8. ANDRADE. O observador no escritório, p.7-8. fatos e conversações que possam justificá-lo no futuro, se tiverem em conta o julgamento histórico. Neste caso, o diário valerá como documento de arquivo. Mas o escritor não precisa justificar-se, a não ser pela obra. Ninguém o obriga à anotação íntima, a esse mirar-se no espelho do presente. Então, se escreve o diário, há de ser por força de motivação psicológica obscura, inerente à condição de escritor, alheia à noção de utilidade profissional. Não pensei nisto, anos a fio, ao encher cadernos com anotações sobre o meu dia a dia que jamais pretendi viessem a ter importância documental, como não têm. O impulso de escrever para mim mesmo, em caráter autoconfessional, ditou os feixes de palavras que fui acumulando e que um dia... destruí. Mas a própria destruição tem caprichos. Do conjunto sacrificado salvaram-se alguma páginas que hoje reúno em livro, depois de tê-las, na maio parte, colocado em minha coluna no Caderno B do Jornal do Brasil. Animou-me a ingênua presunção de que possam dar ao leitor um reflexo do tempo vivido de 1943 a 1977, menos por mim do que pelas pessoas em volta, fazendo lembrar coisas literárias e políticas daquele Brasil sacudido por ventos contrários. Fui, talvez, observador no escritório. ${ }^{8}$

Este trecho mostra que as palavras acumuladas no espaço íntimo do diário que, segundo o autor, só serviam para atender ao impulso de escrever, tornaram-se um livro de importância documental e literária, pelo registro que faz daquela época,

EM TESE
BELO HORIZONTE
N. 3

SET.DEZ. 2016 por apresentar não só aspectos da vida íntima de Drummond, mas em grande parte, as personalidades literárias e históricas, as tentativas daquela geração de escritores de organizarem o "momento literário", as discussões sobre as produções daquele período, a repercussão das publicações, a maneira engajada dos escritores modernistas e ainda por fazer esses registros fugindo à objetividade do texto jornalístico, manejando o "dizer" com uma forma própria do texto literário e de um estilo característico de Drummond.

O que assegura o valor desse diário não é somente uma possível revelação de segredos para a satisfação da curiosidade do público, mas a força documental e literária que o livro oferece a seu leitor. Mário Faustino no artigo "Poesiaexperiência" comenta a importância da poesia de Drummond como documento crítico, e o que ele afirma sobre a produção poética vale também para este diário, pois assim como sua poesia, o Observador vale por ser:

Um documento crítico de um país e de uma época (no futuro quem quiser conhecer o Geist brasileiro, pelo menos de entre 1930 e 1945, terá que recorrer muito mais a Drummond que a certos historiadores, sociólogos, antropólogos e filósofos nossos...) e um documento 'apologético do Homem'.

Em seus "desabafos abafados"10, o autor vai se revelando como o grande poeta "que marca o seu tempo, sendo por ele
FAUSTINO Poesia-experiência p.90

10. Em entrevista concedida à filha Maria Julieta e publicada no Jornal O Globo, Drummond usa a expressão "desabafos abafados" para se referir ao diário $O$ observador no escritório. 
11. BRAYNER. Fortuna Crítica 1: Carlos Drummond de Andrade, p. 266.

12. Expressão que se encontra no poema "Europa, França e Bahia". Cf. ANDRADE. Antologia Poética, p.27. marcado"11. Seu impulso de escrever, na tentativa de passar sua própria vida a limpo, acaba passando a limpo também um período importante da história do Brasil e seus "olhos brasileiros"12 procuravam investigar o que estava por trás dos acontecimentos que ele registrava.

Desde o título, o diário de Drummond destaca-se por uma posição dentro daquele tempo: a de um observador. De seu ponto de observação, metaforizado pela janela do escritório, Drummond confessa um viver sempre em conflito com a sociedade, com as questões políticas, com os valores tradicionais e até com ele mesmo. Como testemunha de um tempo o narrador desse diário desdobra-se em dois: um observado do país e um observador de si mesmo, de sua própria intimidade. As anotações tendem para o registro da exterioridade, o que se justifica pela natureza reservada do autor, manifestada na preocupação em preservar os acontecimentos relacionados à vida privada. $\mathrm{O}$ fato de o próprio autor ter feito a seleção dos trechos para o livro, escolhendo menos registros pessoais do que históricos, também reforça que o desejo de perpetuar fatos e figuras do Brasil daquele período era maior do que o de falar de si.

Como testemunha de seu tempo, este observador vai atestar o lugar social-político de onde observa e que também o título sugere: "o escritório". O espaço, no qual Drummond trabalhou como funcionário público, faz lembrar a monotonia das tarefas burocráticas e a atitude reflexiva de quem vive na solidão de um escritório. Esse espaço era também o lugar do escritor, ou seja, do intelectual no Brasil daquele momento. Drummond foi funcionário-público durante 35 anos, e este "lugar" que ocupava deixava-o em uma condição incômoda, pois sua "ligação" com o governo soava contraditória com a pressuposta liberdade de expressão que o artista deve exercer. Isso fica evidente no estilo dos registros, em especial, naqueles referentes aos momentos de repressão política. ${ }^{13}$

De sua mesinha no escritório, Drummond parece não querer deixar escapar nada. Registra o que vê acontecer em seu país, os encontros com os amigos, as coisas banais do dia a dia e acrescenta ao que conta, aquilo que ele pensa sobre tudo isso, usando em sua narrativa a ironia e o humor que lhe são característicos. É possível perceber que, ao escolher o que registrar, ele parece ter sido movido não só pela observação, mas também por uma sensibilidade que transforma até um acontecimento banal em matéria importante que deve ser registrada. Quando medita sobre esses pequenos acontecimentos, o autor registra não o simples fato, mas uma espécie de disparo sentimental despertado pelo momento vivido. $\mathrm{O}$ momento, o instante, o acontecimento banal faz com que o Drummond comece um processo que se inicia com a observação e caminha para a reflexão crítica. Sobre essa capacidade do autor de transformar o que parece irrelevante em algo
13. Em 1928, Drummond entrou na burocracia. Esteve inicialmente na Secretaria de Educação, com Mario Casassanta, indo em 1930 para a Secretaria do Interior, onde trabalharia com Cristiano Machado (três meses) e, posteriormente, com Gustavo Capanema (três anos). A noite, trabalhava no Diario de Minas, e depois no Governo). Esteve tombém jornais dos Diários Associados. Quando Gustavo Capanema vio para o Rio, acompanhou-o, tendo ficado a seu lado até 1945 , quando se demitiu por questões políticas. Nesse mesmo ano foi com Álvaro Moreyra, Aidano de Couto Ferraz e outros, diretor da Tribuna Popular, cargo que ocupou apenas por três meses. Ainda em 1945, graças à boa vontade de Rodrigo M. F. de Andrade e Gustavo Capanema, foi trabalhar na Diretoria do Patrimônio Histórico e Artistico Nacional, onde chefiara, mais tarde a Seção de História, na Divisão de Estudos e Tombamentos. Ficará no cargo até 1962, quando e aposentado, depois de 35 anos de serviço público. Cf. BRAYNER. Fortuna Crítica 1: Carlos Drummond de
Andrade, p.58. 
14. CANDIDO. Poesia e ficção na autobiografia, p. 17.

15. ARFUCH. O espaço biográfico, p. 15. grandioso e deslizar do papo para a reflexão, especialmente na prosa, Candido (2011) no texto "Poesia e ficção na autobiografia" diz:

É em Montaigne que penso quando vejo Drummond, numa prosa que se apresenta como algo irrelevante, deslizar do papo para as reflexões de um alcance e densidade que nos fazem incluí-lo na família mental dos que ensaiam o pensamento, a pretexto de motivos inesperados; mesmo quando ele volta de repente a algo que parece insignificante, como se quisesse, por meio desse particular corriqueiro, quebrar o 'ensaio' e refazer a 'crônica.'. ${ }^{14}$

Mais do que registros históricos ou confessionais, há no diário drummondiano uma tentativa de "apreender a qualidade evanescente da vida" 15 , a busca pela perpetuação do instante, o desejo de vencer a ação voraz do tempo. Para Leonor Arfuch, os registros autobiográficos representam esta luta:

A simples menção do 'biográfico' remete, em primeira instância, a um universo de gêneros discursivos consagrados que tentam apreender a qualidade evanescente da vida opondo, à repetição cansativa dos dias, aos desfalecimentos da memória o registro minucioso do acontecer, o relato das vicissitudes ou a nota fulgurante da vivência, capaz de iluminar o instante a totalidade. Biografias, autobiografias, confissões, memórias,

EM TESE
BELO HORIZONTE diário íntimos, correspondências dão conta, há pouco mais de dois séculos, dessa obsessão por deixar impressões, rastros, inscrições, dessa ênfase na singularidade, que é ao mesmo tempo de busca de transcendência. ${ }^{16}$

No Observador, vemos o poeta mineiro tornando importante e permanente o que, segundo ele, havia anotado apenas como uma forma de expurgo. A mudança do suporte textual, do caderno de anotações para o jornal e, posteriormente, para o livro diário e a troca do espaço íntimo para o público, colaboram para a problematização do gênero e nos levam a alguns questionamentos: esses registros seriam crônicas ou apenas textos confessionais? Quais as características desses textos ou tratamento dos assuntos selecionados que os aproximam ora de um gênero, ora de outro? É possível classificá-los? Tratando-se de uma escrita de si, qual seria a intenção do autor ao publicá-los? O que a seleção feita pelo próprio autor revela sobre suas pretensões? Haveria literariedade nesses registros? Em que medida esses registros são textos confessionais?

Quando Drummond decide dar a esses escritos o caráter de livro, selecionando e organizando os trechos que gostaria de ver publicados, acaba revelando seu desejo de, consciente ou não, torná-lo literário. Os registros mostram-se como literários pelo trabalho com a linguagem, que reiteram o estilo drummondiano conciso, irônico, inquieto e também evidenciam uma subjetividade contraditória e tensa, sendo 
uma escrita para, mais do que documentar fatos, causar um efeito literário em seu leitor. A fim de alcançar este efeito, Drummond usa da coloquialidade, do humor, da ironia sempre presente em sua obra, de uma seleção do vocabulário e da sintaxe que pedem ao leitor um olhar com mais acuidade ao texto, de movimentos narrativos de sumarização e expansão que sempre deixam algo ainda por revelar, de figuras de ritmo, da presença de elementos inusitados, como exclamações, interjeições, discursos diretos, recorrendo, enfim, a vários procedimentos do arcabouço literário.

Assim, mais do que tudo, é o desejo da escrita que se vê no diário drummondiano. Encher esses cadernos com anotações pessoais misturadas a trechos que desvelam a sensação do observador diante dos fatos históricos era, segundo o poeta, apenas uma forma de atender ao desejo da escrita autoconfessional. Dessa forma, as motivações dele em relação à elaboração deste diário lembram a justificativa apresentada por Lejeune:

Mantém-se enfim um diário porque se gosta de escrever. É fascinante transformar-se em palavras e frases e inverter a re lação que se tem com a vida ao se autoengendrar. [...] O prazer é ainda maior por ser livre. Qualquer um se sente autorizado a manejar a língua como quiser, escrever sem medo de cometer erros. Pode-se escolher as regras do jogo. Ter vários cadernos. Misturar os gêneros. Fazer de seu diário, ao mesmo tempo, o observatório da vida e o ponto de encontro de seus escritores. ${ }^{17}$
Nos vários cadernos de anotações, é possível perceber que Drummond escolheu as regras do jogo e fez de seu diário um "observatório da vida". Nota-se, além desse "manejar a língua", uma mistura de gêneros em seu diário, o que atesta a existência dessa liberdade ao escrever, mencionada por Lejeune.

O tom de reflexão e crítica a tudo que registra e a inteligência sensível do poeta mineiro fazem com que as anotações a respeito de fatos históricos ganhem status de crítica e denúncia. Da mesma forma, os trechos mais confessionais estão perpassados por um tom intimista, algumas vezes bastante emotivo, desabafos mesmo, como o próprio autor afirma, revelando um sujeito que tenta evitar o extravasamento de emoções, o que por vezes, foge a seu controle. Como dito, tanto em um caso como no outro, nota-se que as fronteiras continuam oscilantes e os gêneros se confundem, tendendo sempre a fragilizar o discurso documental pela inserção de recursos literários

Sendo assim, esta análise pretende ampliar o conhecimento e a compreensão do diário de Drummond, mas também destaca a relevância dessa obra que se insere na fronteira da Literatura e da História, e que atesta as impressões de uma importante testemunha de um tempo tumultuado no país. Espera-se, assim, que a abordagem escolhida contribua para as reflexões a respeito d'O Observador no escritório, e para os estudos sobre as posições deste importante autor diante de seu tempo e da literatura da época.
7. LEJEUNE. O pacto autobiográfico p. 264-265.
EM TESE v. 22

SET.-DEZ. 2016

SILVA. 0 observador no escritório, um tempo filtrado pelo modo de ver

P. 309-323 
18. CANDIDO. Poesia e ficção na autobiografia, p.66.

19. CANDIDO. Poesia e ficção na autobiografia, p.67.
Lendo o Observador, tem-se a mesma impressão mencionada por Candido:

A impressão é de que o poeta inclui deliberadamente a si mesmo na trama do mundo como parte do espetáculo, vendo-se de fora para dentro. Dir-se-ia então que a tonalidade dos últimos livros é fruto de uma abdicação do individualismo extremado em favor de uma objetividade que encara serenamente o eu como peça do mundo. ${ }^{18}$

Encarando a si mesmo como peça do mundo, na escrita do diário vemos que "a experiência pessoal se confunde com a observação do mundo e a autobiografia se torna heterobiografia, história simultânea dos outros, da sociedade, sem sacrificar o cunho individual, filtro de tudo [...]”. ${ }^{19}$

Neste trabalho, assumimos esta posição de Candido, consideramos, portanto, que o diário de Drummond mais do que uma escrita autobiográfica, constitui-se em uma heterobiografia, pois os registros além de serem mais do outro do que de si, sempre passam pelo filtro da subjetividade, ou seja, pelo modo de ver de um observador que deixa rastros de suas impressões a respeito de tudo que anota.

Ao decidir publicar as entradas do diário, Drummond reafirma a preocupação em fazer registro de um tempo, preservá-lo para que o futuro leitor possa "lembrar coisas literárias e políticas daquele Brasil sacudido por ventos contrários". ${ }^{20}$ Os ventos contrários sopravam naquele tempo marcado pelo final da "Era Vargas", início do "Período Democrático" e instauração da ditadura militar. Era diante desse contexto que o poeta se via movido pelo impulso de escrever e ia fazendo da palavra um meio para observar a vida e registrar não só os fatos, mas o que pensava sobre eles, não só os homens, mas o que eles eram sob o seu olhar.

Além do desejo de preservar um tempo passado/vivido, a apreensão diante do esvanecimento futuro também parece ser força motivadora nesse impulso de escrever. A respeito desse desejo de contribuir para a fixação e registro de um tempo, Lejeune escreve:

Mantemos um diário para fixar o tempo passado, que se esvanece atrás de nós, mas também por apreensão diante do nosso esvanecimento futuro. Mesmo secreto, a menos que se tenha coragem suficiente para destruí-lo, ou para mandar enterrá-lo consigo, o diário é apelo a uma leitura posterior: transmissão a algum alterego perdido no futuro, ou modesta contribuição para a memória coletiva. Garrafa lançada ao mar. E também investimento: o valor da informação de um diário aumenta com o tempo. É como um seguro de vida que se alimenta tostão por tostão, dia após dia, com depósitos regulares. ${ }^{21}$
20. ANDRADE. O observador no escritório, p.8.

EM TESE

BELO HORIZONTE

v. 22

N. 3

SET.-DEZ. 2016

SILVA. 0 observador no escritório, um tempo filtrado pelo modo de ver

P. 309-323

21. LEJEUNE. O pacto autobiográfico p. 264-265. 
Movido por essas duas preocupações, a de eternizar o tempo e a de ser eterno, Drummond não foi capaz de destruir todas as anotações e nem mesmo as preservou apenas no espaço da escrita íntima. O diário, a priori feito sem pretensões de justificar-se ou de ser documento importante, foi publicado por iniciativa do próprio autor e como "garrafa lançada ao mar", mostrou-se como um apelo do poeta mineiro ao leitor futuro.

Essa construção da sua narrativa pode ser percebida no diário de Drummond, pois nele vemos o registro que não pretende apenas "dizer o que houve", mas também "dizer o que o autor diz que viu”. Para além do registro do fato, o que interessa é o modo escolhido para registrá-lo, é o ponto de olhar e a reflexão que o observador apresenta sobre o que anota. Não se trata de fazer registro de maneira objetiva e impessoal, sendo fiel ao fato como na escrita jornalística, mas de anotar o que observou dizendo o que "viu, sentiu e experimentou".

O observador no escritório estaria, portanto, nessa fronteira entre a crônica e o diário devido a uma combinação de características desses dois gêneros e também à mudança do meio de publicação. Como cronista, Drummond escrevia sem se desprender da linguagem poética; como poeta também não escapava da visão por vezes mais objetiva e atenta de um jornalista; e na escrita íntima, continuava revelando a presença do cronista e do poeta em suas anotações no livro/diário. Candido, em "Drummond prosador: singularidade do traço", ao falar sobre essa miscelânea de gêneros, afirma que "Na sua poesia há ficção e crônica; na sua crônica, poesia e ficção; na sua ficção, crônica e poesia - tudo formando o que para ele decerto são tentativas, mas para nós são realizações completas e exemplares”.

Essa hibridez presente na produção do autor também se revela no diário. A mão nervosa do repórter, a expressão do eu na escrita confessional, o desejo de registrar o fato, a vontade de expurgar emoções faz com que o leitor reconheça nessas anotações a complementaridade mencionada por Drummond entre a Literatura e o Jornalismo, e se veja diante ora de um cronista, ora do eu presente na escrita de si, mas sempre guiado por um texto enriquecido pelas impressões do observador.

Nesse espaço, o observador vai se revelando como um sujeito marcado por sua historicidade, que pretende por meio da escrita "compreender" a si, ao outro e às circunstâncias daquele período. Assim, considerando a existência da subjetividade junto à intersubjetividade, pode-se pensar que o diário de Drummond é como "toda biografia ou relato da experiência é, num ponto coletivo, expressão de uma época, de um grupo, de uma geração, de uma classe, de uma narrativa comum de identidade".22 
Em O observador, o autor estaria fazendo "fábula da própria vida" ${ }^{23}$, como diz Arfuch, já que, mesmo apoiado na realidade, é na maneira escolhida para contar a vida que se percebe a literariedade do texto. A vida que se conta não é tal qual o autor viveu, é o que escolheu contar, são fragmentos do vivido, portanto, é resultado da escrita.

Essa construção da experiência vivencial no diário de Drummond relaciona-se com a seleção dos trechos feita pelo próprio autor, a destruição de outros e ainda a manutenção de alguns registros mais íntimos em segredo. Ao "guardar" trechos que descreviam a vida familiar, o autor revela-se como alguém que tenta fugir da subjetividade, optando por falar mais do outro que de si mesmo, como foi dito acima.

O diário desse autor constrói-se, então, a partir de um jogo entre velar e desvelar em que o fato é registrado e enriquecido pelas impressões do observador. Seja nas crônicas dos dias comuns ou nas crônicas mais históricas, o observador deixa o dizer subentendido por meio dos jogos de linguagem, do humor, do tom coloquial, das elipses, da sumarização e, por outro lado, desvela pela confissão, pela emoção escapada. Em relação aos registros mais próximos da crônica, há ainda outra divisão: algumas anotações assemelham-se à acepção de crônica como um registro mais histórico, mais objetivo, sendo o narrador uma espécie de testemunha da história; outras se relacionam à crônica mais moderna, mais coloquial e com um pretenso tom mais pessoal. Em ambas, no entanto, há uma preocupação para que a linguagem seja construída de modo a causar um efeito no leitor, indo além da escrita meramente informativa.

Não é apenas o fato de ser expressão de uma época, registro de um tempo que importa, mas o modo escolhido para contar, os recursos literários que o autor utiliza como as figuras de linguagem, intertextualidades, a ironia, o humor, a ambiguidade, as elipses, a pontuação, o jogo do dizer sem dizer, é esse manejo da linguagem que faz o registro ir do documental ao literário.

Dessa forma, os "desabafos abafados" de Drummond se aproximam dos engasgos mencionados pela poetisa Ana Cristina César, outra autora de diário, "Você está precisando loucamente confidenciar umas tantas coisas [...], tem uma coisa que está engasgada, que precisa ser dita para alguém, e aí, muitas vezes, a gente, de puro engasgo, de necessidade mesmo, apela para o diariozinho". ${ }^{24}$

Enquanto observava o outro, o país e até a ele mesmo, a "necessidade de fornecer matéria para conversa de pessoas velhas e novas", "a presunção de dar reflexo do tempo vivido de 1943 a 1977", o desejo da escrita, o autoexame impregnado pela personalidade contraditória e cética, tudo isso o animava, fazia-o acumular palavras, e deixar rastros naquelas anotações. E na "vida presente", diante dos "homens
24. CÉSAR. Correspondência Incompleta, p.259. 
25. ANDRADE. O observador no escritório, p. 97 presentes", o observador no escritório "para não sofrer com o espetáculo, preferia fechar os olhos. Eles, porém, inspecionavam por conta própria, máquina fotográfica a funcionar independente" 25 dele.

\section{REFERÊNCIAS}

ANDRADE, Carlos Drummond de. As impurezas do branco Carlos Drummond de Andrade; Posfácio Betina Bischof $-1^{\text {a }}$ ed. São Paulo: Companhia das Letras, 2012.

ANDRADE, Carlos Drummond de. Alguma poesia. $9^{\mathrm{a}}$ ed. Rio de Janeiro: Record, 2008.

ANDRADE, Carlos Drummond de. Antologia Poética. (organizada pelo autor). 60 ed. Rio de Janeiro: Record, 2008.

ANDRADE, Carlos Drummond de. Confissões de Minas. São Paulo: Cosac Naify, 2011

ANDRADE, Carlos Drummond de. Lição de coisas. $1^{\text {a }}$ ed. São Paulo: Companhia das Letras, 2012

ANDRADE, Carlos Drummond de. Poesia Completa. $1^{\text {a }}$ ed. Rio de Janeiro: Nova Aguilar, 2002

ANDRADE, Carlos Drummond de. $\mathbf{O}$ observador no escritório: páginas de diário. Rio de Janeiro: Record, 1985.

ANDRADE, Carlos Drummond de. Sentimento do mundo. $1^{\text {a }}$ ed São Paulo: Companhia das Letras, 2012.
ANDRADE, Carlos Drummond de. Tempo, vida poesia; confissões no rádio. Rio de Janeiro, Record, 1987.

ANDRADE, Mário de. A lição do amigo: Cartas de Mário de Andrade a Carlos Drummond de Andrade. Rio de Janeiro: Olympio, 1982

ANDRADE, Mário de. A medida psicológica. In: BRAYNER, Sônia (Org.). Fortuna Crítica 1: Carlos Drummond de Andrade. Direção de Afrânio Coutinho. Rio de Janeiro: Civilização Brasileira, 1977. p. 67-72.

ANDRADE, Mário de. Aspectos da literatura brasileira. São Paulo: Martins, 1978.

ANDRADE, Maria Julieta. Maria Julieta entrevista Carlos Drummond de Andrade. Áudio MP3. Rio de Janeiro: Ondaalta 2008. CD-ROM

ARFUCH, Leonor. 0 espaço biográfico: dilemas da

subjetividade contemporânea. Rio de Janeiro: EdUERJ, 2010.

BLANCHOT, Maurice. O livro por vir. Tradução Leyla PerroneMoisés. São Paulo: Martins Fontes, 2005.

BRAYNER, Sônia (Org.). Fortuna Crítica 1: Carlos Drummond de Andrade. Direção de Afrânio Coutinho. Rio de Janeiro: Civilização Brasileira, 1977

CANDIDO, Antonio. Poesia e ficção na autobiografia. In: A educação pela noite. Rio de Janeiro: Ouro sobre Azul, 2011. p.61- 83. 
CANDIDO, Antonio. A vida ao Rés-do-Chão. In: A Crônica. $\mathbf{O}$ gênero, sua fixação e suas transformações no Brasil. Campinas, SP: Editora da UNICAMP e Fundação Casa Rui Barbosa, 1992

CANDIDO, Antonio. Drummond prosador: singularidade do traço. Revista do Brasil, Rio de Janeiro, n.2, 1984. Republicado parcialmente, devido a incorreções, no número seguinte da Revista do Brasil, Rio de Janeiro, n. 3, 1985. Republicado novamente em: Recortes. São Paulo: Companhia das Letras, 1993 3 ed. rev. pelo autor: Rio de Janeiro: Ouro sobre Azul, 2004.

CANDIDO, Antonio. Literatura e Sociedade. $8^{\mathrm{a}}$ ed. São Paulo: T. A. Queiroz, 2000; Publifolha, 2000.

CANDIDO, Antonio. Inquietudes na poesia de Drummond. In Vários escritos. 2a ed. São Paulo: Livraria Duas Cidades, 1977.

CANDIDO, Antonio. Dialética da Malandragem: caracterização das Memórias de um sargento de milícias. In: Revista do Instituto de estudos brasileiros. $n^{\circ}$ 8. São Paulo: USP, 1970 p.67-89.

CANDIDO, Antonio; [et. al.]. A Crônica. $\mathbf{O}$ gênero, sua fixação e suas transformações no Brasil. Campinas, SP: Editora da UNICAMP e Fundação Casa Rui Barbosa, 1992.

CÉSAR, Ana Cristina. Correspondência Incompleta. Rio de Janeiro: Aeroplano, 1999

FAUSTINO, Mário. Poesia-experiência. In: BRAYNER, Sônia (org). Carlos Drummond de Andrade. (Fortuna Critica, 1). $2^{\mathrm{a} e d .}$ Rio de Janeiro: Civilização Brasileira, 1977, p.88-97.
LEJEUNE, Philippe. $\mathbf{O}$ pacto autobiográfico. De Rousseau à internet. Organização Jovita Maria Gerheim Noronha. Tradução Jovita Maria Gerheim e Maria Inês Coimbra Guedes. Belo Horizonte: EdUFMG, 2008. 404p.

TRAVANCAS, Isabel. Drummond na imprensa: algumas crônicas das décadas de 1940 e 1950. In: Intercom - Revista Brasileira de Ciências da Comunicação. São Paulo, v. 31, n. 2, p. 123-138, jul./dez. 2008.

\section{WEB SITES}

CARTA CAPITAL. Aguá: a crônica da falta de bom senso.

CANTO, Reinaldo. 16 de fevereiro de 2014. Disponível em: http:// www.cartacapital.com.br/sociedade/agua-a-<cronica-da-falta-debom-senso-7565.html> Acesso em: 01/03/2015

Acervo digital: Jornal do Brasil. <http://bndigital.bn.br/ hemeroteca-digital/>

$<$ http://www.pactoaudiovisual.com.br/mestres_final/drummond/ transcricao.htm>

$<$ https://cpdoc.fgv.br/producao/dossies/Jango/biografias/ magalhaes_pinto. $>$

<https://cpdoc.fgv.br/producao/dossies/AEraVargas1/biografias/ gustavo_capanema>

$<$ https://cpdoc.fgv.br/producao/dossies/AEraVargas1/biografias/ francisco_campos> 
$<$ http://vivaitabira.com.br/2014/index.php/luiz-camillo-deoliveira/>

JORNAIS

ANDRADE, Carlos Drummond de. A pipa. Jornal do Brasil. Rio de Janeiro: 9 de jan. 1954

ANDRADE, Carlos Drummond de. Meditação do eleitor 3144.

Folha da Manhã. Rio de Janeiro: 14 de out. 1945.

ANDRADE, Carlos Drummond de. CIAO. Jornal do Brasil. Rio de Janeiro: $1984 \mathrm{~s} / \mathrm{p}$

EMEDIATO, Luiz Fernando. Entrevista de Carlos Drummond de Andrade. Estado de Sáo Paulo. 15 de ago. 1987. Caderno 2. 